\title{
Factors contributing to the strength of national patent protection and enforcement after TRIPS
}

Nikolaos Papageorgiadis, Chengang Wang and Georgios Magkonis ${ }^{1}$

In this paper we study the determinants of the strength of patent enforcement in 43 member countries of the World Trade Organization (WTO) between 1998 and 2011, a period after the signing of the Trade-Related Aspects of Intellectual Property Rights (TRIPS) agreement. We do so by building on and expanding the seminal work of Ginarte and Park (1997) on the preTRIPS determinants of patent rights in the years 1960-1990. We find that in the years after TRIPS was signed, the strength of patent enforcement of a country is positively determined by two variables that signify the usage of the patent and intellectual property system, and the number of patent and trademark applications. We also find that the level of research and development expenditure, the quality of human capital, and the level of development of a country have positive effects on the strength of the enforcement of patent law in practice. Intellectual property rights enforcement is one of the key investment-related policies included in the United Nations Conference on Trade and Development (UNCTAD) Investment Policy Framework for Sustainable Development. Identifying the determinants of strong patent systems will help policymakers at the national and supranational levels to design and implement effective policies that strengthen national patent systems, thereby enhancing economic benefits such as greater levels of commercialization of intangible assets and greater levels of international trade and investment.

Keywords: patent rights; patent system; patent law; patent enforcement; TRIPS

\footnotetext{
${ }^{1}$ Nikolaos Papageorgiadis is with the University of Liverpool \& Uppsala University, Chengang Wang with the University of Bradford and Georgios Magkonis with the University of Portsmouth. The corresponding author is Nikolaos Papageorgiadis (n.papageorgiadis@liverpool.ac.uk)
} 


\section{Introduction}

The signing of the Trade-Related Aspects of Intellectual Property Rights (TRIPS) agreement in 1994 was a key milestone and turning point for the evolution of stronger patent systems in World Trade Organization (WTO) member countries. The TRIPS agreement set the minimum regulatory standards of intellectual property (IP) protection with an aim to "reduce distortions and impediments to international trade” (WTO, 2018). This was because the strength of a country's patent system is an important factor that affects international investments by influencing e.g. the level and extent to which transnational corporations consider investing in and transferring advanced technological assets to a host country (UNCTAD, 2010, 2013, 2015). Effective national patent systems comprise two components: (a) the strength of patent law on the books, and (b) the strength of the enforcement of patent law in practice (Papageorgiadis and McDonald, 2019). Since the signing of TRIPS, patent law protection in developed and developing WTO member countries has strengthened significantly and become more harmonized (Taubman et al., 2012). While differences in patent legislation do exist, the divergence, especially in terms of minimum standards, is not as wide as it used to be prior to the signing of TRIPS (Park, 2008).

In contrast, the implementation of the TRIPS agreement did not affect the levels of strength of the enforcement of patent law in practice, in the way that this is e.g. applied by public enforcement agents (Brander et al., 2017). Although the TRIPS agreement set clear requirements for the inclusion of specific enforcement procedures in the legislative frameworks of countries, it did not set obligations on how effectively patent law should be enforced in practice (WTO, 2018). Therefore, although a strong patent legislative framework may exist in the post-TRIPS patent system of a particular country, these laws may not be enforced in practice by public enforcement agents (Arora, 2009). As a result there are still wide differences in the levels of patent enforcement strength between countries (Papageorgiadis et al., 2014), and these differences have now become the dominant factor of the divergence between the patent systems of WTO member countries after the signing of TRIPS (Correa, 2009; Fink, 2009). In fact, weak levels of patent enforcement strength are commonly identified as an impediment to international trade and investment, turning the levels of patent enforcement strength into a common area of discussion in bilateral and multilateral trade negotiations (Papageorgiadis et al., 2014; Alexiou et al., 2016). For example, in the recent trade dispute between the United States and China, the Trump administration announced "plans for a 25 per cent tariff on 1,333 Chinese products ranging 
from industrial robots to locomotives in retaliation for what it said had been decades of statebacked [IP] theft by Beijing” (Financial Times, 2018).

Identifying the key factors that contribute to the strengthening of patent law protection and enforcement can help policymakers design and implement effective policies that will strengthen the patent system of their country or region. Strengthening a country's patent system to a level that is compatible with a country's development and technological capabilities is desirable as this is expected to boost economic growth, by attracting higher levels of foreign direct investment (FDI) and innovation, and lead to greater levels of commercialization of intangible assets (Pereira, 2006; UNCTAD, 2015). For instance, the strength of the United Kingdom's IP system has enabled growth in IP-protected intangible assets investments from $£ 47$ billion in 2000 to $£ 70$ billion in 2014 (UK IP Office, 2017). The potential benefits of strong patent systems have motivated the IP offices of some countries to design detailed strategic actions with an aim to improve their IP systems. Such was the case with the 10-year IP master plan of Singapore, which initiated policies that can enable Singapore to strengthen its IP system and become an IP hub in the region. The reforms it implemented involved giving research and development (R\&D) incentives to small and medium-sized companies, upgrading the IP capabilities and expertise of the local workforce, and boosting the number of patent applications in the country (Government of Singapore and Intellectual Property Office of Singapore, 2017). Similarly, China's $12^{\text {th }}$ five-year plan (20112015) incentivized Chinese firms to make use of the patent system by subsidizing the cost of patent applications (U.S.-China Economic and Security Review Commission, 2011). The main expectation for such subsidies is that as the number of patent owners in a country rises, this will increase the pressure on public patent enforcement agents to enforce patent law more effectively in practice (Yang et al., 2004). The outcome of such initiatives takes time to materialize, and therefore the transition of a country's patent system from weak to strong is expected to take years or even decades (Peng et al., 2017).

The determinants of patent protection strength was the focus of the seminal work by Ginarte and Park (1997), which has been cited more than 1,500 times according to Google Scholar. ${ }^{2}$ They investigated the determinants of patent protection of 110 countries in 19601990, a time period prior to the signing of the TRIPS agreement, and found that R\&D activity, market freedom and openness were important determinants of the strength of

\footnotetext{
${ }^{2} 1,568$ citations as of November 2018.
} 
national patent law protection as it appears on the books. In other words, these three factors were important characteristics of countries that offered strong patent law protection preTRIPS. However, two decades after the publication of Ginarte and Park's study, and after the signing and implementation of TRIPS, patent systems have evolved considerably, and there is no updated empirical evidence regarding the determinants of (a) the strength of patent law protection, and (b) the strength of the enforcement of patent law in practice in the post-TRIPS period.

In this research note we update and expand the study by Ginarte and Park (1997) and make two contributions to the international business literature studying patent systems. First, we study the previously unidentified determinants of the strength of enforcement of patent law in practice for 43 WTO member countries in the post-TRIPS years, 1998-2011. We follow the same methodology as Ginarte and Park; however, we use the composite index of patent systems strength developed by Papageorgiadis et al. (2014) to approximate for the strength of the enforcement of patent law in practice (Ahammad et al., 2018; Papageorgiadis et al., 2019). ${ }^{3}$ We find strong and consistent evidence that higher numbers of patent and trademark applications filed in a country have a significantly positive effect on the strengthening of the enforcement of patent law in practice. In addition, we find that $R \& D$ expenditure, the level of economic development and the quality of human capital also stimulate the strengthening of patent enforcement. Second, we update the Ginarte and Park study by investigating the determinants of the strength of protection of patent law in the period after TRIPS. We find consistent evidence that the level of R\&D expenditure in a country and the level of economic development continue to be two important determinants of the strength of patent law in WTO member countries in the post-TRIPS time period. We also find evidence to suggest that the quality of human capital in a country is a new post-TRIPS determinant of the strength of patent law.

In the next section, we briefly discuss the two complementary measures used as proxies for two distinct aspects of the strength of patent systems, the strength of patent enforcement and the strength of patent law on the books (Papageorgiadis and Sharma, 2016). Following the Ginarte and Park (1997) empirical approach, in section three we present the empirical model, estimation, and variables applied and focus the discussion on the additional (contemporary) variables that we incorporated in the estimation. We provide the results and

\footnotetext{
3 The index of Ginarte and Park and its update by Park (2008) measure the strength of patent law protection in a country but not the strength of patent enforcement (Brander et al., 2017).
} 
discussion of the findings in section four. In section five, we discuss the policy implications of the study and make suggestions for future research.

\section{Measures}

The dependent variable for the estimation of the determinants of the strength of patent law is the version of the Ginarte and Park (1997) index updated by Park (2008). This version of the index is the most widely used in empirical studies in the literature. The scores of the Park (2008) index capture the availability of patent-related legislation that enables the functioning of a patent system. The index is composed of five components that capture the (i) granting of patent rights for specific innovations, (ii) signatory status of a country to international treaties that are relevant to patent rights (such as TRIPS), (iii) duration of protection for the patent rights granted, (iv) availability of legal mechanisms that can enable the enforcement of patent rights and, (v) legislation that can potentially restrict patent rights. The unweighted sum of these five components determines the overall score for each of the countries included in the index.

We use the index by Papageorgiadis et al. (2014) as the dependent variable for the estimation of the strength of the enforcement of patent law in national patent systems in practice. It is important to note that the fourth component of the Ginarte and Park (1997) index, which captures the availability of legislation that can enable the enforcement of patent rights, has been commonly misperceived as a measure of patent enforcement strength (Arora, 2009; Brander et al., 2017). In fact, as Park (2008, p. 761) highlights in the latest update of the index: "This index was designed to provide an indicator of strength of patent protection, not the quality of patent systems”. In contrast, the Papageorgiadis et al. (2014) index uses both reports and perceptions of effectiveness to measure the strength of the enforcement of patent law in practice in the time period since the signing of TRIPS (Papageorgiadis and McDonald, 2019). It is the only longitudinal index to do so, and in so doing, this composite indicator measures the strength of eight enforcement-related components of national patent systems, thereby providing the most comprehensive approximation for the overall strength of enforcement of patent law in practice in the literature.

Papageorgiadis et al. (2014) developed the index following methodological recommendations from the Organization for Economic Co-operation and Development (2008). The authors applied a transaction cost rationale to map how ineffective enforcement 
activities, administration, and governing of enforcement-related aspects of a national patent system increase the transaction costs that patent owners face in 48 countries. The index scores are derived using secondary data that proxy for three types of transaction costs: (a) the servicing costs faced by patent owners in terms of the quality of patent administration in a given country, (b) the property rights protection costs incurred as a result of the ineffectiveness of the judiciary and the judicial process in a country, and (c) the monitoring costs that originate from the ineffectiveness of public and private agencies (e.g. police and customs) in enforcing patent rights, as well as the overall societal attitudes towards the enforcement-related aspects of patent rights which dictate the acceptability of enforcement actions in a given country.

\section{Empirical model and estimation}

As noted, the empirical approach of this research note follows the Ginarte and Park (1997) study. However, the difference is that we consider the determinants of the strength of patent law as well as the determinants of the strength of patent enforcement. The estimation is based on a panel of 43 WTO member countries for the period 1998-2011, and the estimation model can be written as follows:

$$
y_{i t}=a+x_{i t}+u_{i t}
$$

where $y$ is the proxy of the strength of either patent law (first set of regressions, focusing on the determinants of the strength of patent law only) or the enforcement of patent law in practice (second set of regressions, focusing on the determinants of the strength of the enforcement of patent law in practice), $x$ is the vector of all explanatory variables, lagged by one year to control for potential endogeneity (except for political freedom) and $u_{i t}$ is the error term. ${ }^{4}$ With regards to the explanatory variables, we include the same variables as those used by the Ginarte and Park (1997) study in all specifications. These are (i) GDP per capita, to proxy for the level of economic development (World Bank, 2015a); (ii) R\&D expenditure as a percentage of GDP (World Bank, 2015b); (iii) secondary education enrolment rate, to proxy for the quality of human capital (World Bank, 2015c); (iv) the Index of Economic Freedom,

\footnotetext{
${ }^{4}$ Our data set consists of the following countries: Argentina, Australia, Austria, Belgium, Canada, Chile, China, Colombia, the Czech Republic, Denmark, Finland, France, Germany, Greece, Hong Kong, Hungary, Iceland, India, Indonesia, Ireland, Israel, Italy, Japan, Jordan, Malaysia, Mexico, the Netherlands, New Zealand, Norway, the Philippines, Poland, Portugal, the Republic of Korea, Romania, Russian Federation, the Slovak Republic, South Africa, Spain, Sweden, Switzerland, Thailand, Turkey and the United Kingdom. The number of countries included in our estimations is determined by the availability of data of the Papageorgiadis et al. (2014) index, which provides annual index scores for the years 1998-2011, for a maximum of 43 countries. Our data set therefore includes 43 countries whereas the Ginarte and Park (1997) data set included 48.
} 
to proxy for the level of market freedom in a country (Heritage Foundation, 2015); (v) the sum of volume of exports and imports of a country over GDP, to proxy for the openness of the economy (World Bank, 2015d, 2015e), given that the data of Sachs et al. (1995) used by Ginarte and Park have not been updated with contemporary values; (vi) the political rights data made available by the Freedom House (2015), to proxy for political freedom as the political freedom data of Barro and Lee (1994) (used by Ginarte and Park, 1997) are not available for any of the years considered in our study.

Further to the variables included in the Ginarte and Park (1997) study, we also take into account the potential effects of three additional variables which have become increasingly important in the time period studied. First, we consider the potential effects of the number of patent applications per capita and the number of trademark applications of residents and non-residents (WIPO, 2015). Higher levels of patent and trademark applications in a country indicate the desire of local and foreign companies to gain protection for their IP, as well as to (potentially) effectively enforce their legal rights in practice (Desyllas and Sako, 2013). Higher levels of patent and trademark applications in a country are therefore expected to have a positive effect on the strength of patent law and the strength of the enforcement of patent law in practice. Second, we use a proxy measure for the level of foreign direct investment (FDI), defined as the sum of foreign assets and liabilities as a ratio of GDP (World Bank, 2015f). This is because FDI commonly involves the transfer of technology from the headquarters of a company to a subsidiary in the host market (Dunning and Zhang, 2008). Foreign firms frequently apply pressure to local governments to strengthen patent law and the enforcement of patent law in practice, so that they can retain the same business model as the one used in their home country and successfully appropriate the returns from their innovations in the host country (Zhang et al., 2010).

Table 1 and figure 1 summarise the description of the variables together with the measures used and the sources of the data. Table 2 provides the descriptive statistics and Table 3 the correlation coefficients matrix. ${ }^{5}$

Table 1 goes about here

Figure 1 goes about here

Table 2 goes about here

\footnotetext{
${ }^{5}$ To consider the potential for multicollinearity, we conducted the variance inflation factor test for all specifications. The scores are all below 10, indicating that multicollinearity is not a concern.
} 
Table 3 goes about here-

\section{Results}

Given the presence of country heterogeneity in our sample, we adopted a panel data analysis approach. In the first set of regressions (table 4) we use the Park (2008) index, which proxies for the strength of patent law as our dependent variable. Subsequently, we repeat the same set of estimations (table 5) using the Papageorgiadis et al. (2014) index, which proxies for the strength of enforcement of patent law in practice. We applied the feasible general least squares estimator, controlling for panel heteroscedasticity and first-order autocorrelation. The common characteristic of the three specifications is that we always include the proxies of the variables originally used in the Ginarte and Park (1997) study. Our specifications consider the variables included in that study together with two or all three of the contemporary variables discussed in section three. More precisely, the first specification (column 1) includes all the variables considered by Ginarte and Park (1997) plus FDI and trademark applications per capita. The second specification (column 2) replaces trademark applications per capita with patent applications per capita. The third estimation (column 3) includes all variables considered in our study.

Table 4 goes about here-

Table 5 goes about here

\subsection{Determinants of the strength of patent law}

The results of the estimations focusing on the determinants of the strength of patent law reveal that two pre-TRIPS determinants identified in the Ginarte and Park (1997) study continue to be significant in the era since the signing of TRIPS. More specifically, similar to the finding of Ginarte and Park (1997), we find evidence that the GDP per capita and R\&D expenditure have a positive and significant effect on the strength of patent law protection. The logarithm of real GDP is positive and statistically significant at 1 per cent in all specifications, and the same positive sign is also found for the $R \& D$ expenditure $(p<5 \%)$ variable. Therefore, similarly to the situation in the pre-TRIPS years, the level of economic development and the amount of funds invested in $R \& D$ activities are significant factors that help strengthen patent law protection in all countries in our sample. In addition, while Ginarte 
and Park (1997) found the secondary enrolment variable to have an insignificant effect, we find that in the years since the signing of TRIPS the quality of human capital has a highly significant positive effect on the strength of patent law $(p<1 \%)$. Together, these three aspects of a national economy can help create an ecosystem in which firms can develop higher-quality intellectual assets that require the granting of patent rights so that firms can successfully appropriate the returns on their innovations.

We also find that the variables for market freedom, openness and trademark applications per capita have a negative effect on the strength of patent law protection, with the effect of market freedom being significantly negative $(p<1 \%)$ in all specifications. The results for market freedom and openness are contrary to the results of the Ginarte and Park (1997) study. This finding reveals that the positive association between these two factors and patent law strength since the TRIPS signing has been reversed. This might have been caused by the fact that TRIPS helped to solve the international coordination problem but at the same time induced countries to move away from e.g. the Nash equilibrium degree of IP protection that would be predicted by a structured model of trade and innovation (Grossman and Lai, 2004). In addition, we found that the three variables of political freedom, FDI and patent applications per capita have limited to no statistically significant effect across all three estimations (with the exception of FDI in one of the specifications). The insignificant effect of the political freedom variable is consistent with the results of Ginarte and Park (1997). In contrast, FDI levels and patent applications per capita are found to have no significant effect on the strength of patent law. This could be because the levels of FDI and numbers of patent applications can be mainly considered not as determinants but as outcomes, whose size depends on the strength of patent law. Indeed, there is consistent evidence that strengthening levels of patent law attract higher levels of FDI and lead to more firms seeking to formally register their patent rights in the country (Ushijima, 2013).

\subsection{Determinants of the strength of patent enforcement}

The results of all estimations on the determinants of the strength of enforcement of patent law in practice reveal the significant effect of two different factors compared with those influencing the strength of patent law protection. The results show that the number of patent and trademark applications in a country has a significant positive effect $(p<1 \%)$ on the strength of patent enforcement in almost all specifications. Whereas the number of patent and trademark applications was not found to affect the strength of patent law protection, the ability of patent owners to register and gain patent and trademark rights for the innovations 
that they commercialize in a country was found to positively affect patent enforcement strength. This may be because higher volumes of intellectual asset ownership in a country could increase the number of requests that public patent enforcement agents receive, potentially leading them to increase their efforts, become more effective and achieve stronger enforcement of patent law in practice (Desyllas and Sako, 2013). This is not the case for the strengthening of patent law protection, given that the assigning of patent and trademark rights is an output of patent law protection and that most countries already offer TRIPS-level minimum standards of legal protection.

The three determinants of the strength of patent law since the TRIPS signing, however, were consistently found to have a strong determinant effect on the strength of patent enforcement. GDP per capita, R\&D expenditure and secondary school enrolment consistently had a highly significant positive effect $(p<1 \%)$ on the strength of the enforcement of patent law in practice. This important finding showcases that the determinants of the two aspects of the patent systems of countries in the years after the signing of the TRIPS agreement were positively affected by similar economic factors. Contrary to these three factors, the results of the estimations highlight that the remaining four variables have an insignificant effect on the strength of patent enforcement. We found no evidence that the variables of political freedom and openness have any significant effect. These results were consistent across all estimations. We also found evidence in only one out of three estimations that market freedom had a significant effect on the strength of patent enforcement. Finally, the FDI variable was found to be statistically significant and positive in two out of three estimations. Therefore, there is some evidence that FDI might have a positive effect on the strength of enforcement of patent law in practice.

\section{Conclusions}

Twenty years after the publication of the seminal study by Ginarte and Park (1997) on the determinants of the strength of patent systems, we revisited and expanded their work using data for the post-TRIPS signing time period of 1998-2011. In so doing, we made two contributions to the literature. First, we expanded the focus of the Ginarte and Park (1997) study by considering the determinants of the strength of the enforcement of patent law in practice. The results revealed an important insight on what factors influence the strength of patent enforcement in a country, in that the number of patent and trademark applications has a positive effect on the strength of patent law in practice. This result suggests that the higher the number of IP owners (in the form of ownership of patent or trademark rights) who 
attempt to commercialize their rights in a country, the higher the likelihood that they will apply pressure on public enforcement agents to effectively enforce their rights in a country. Furthermore, we find that higher levels of GDP per capita, R\&D expenditure and quality of human capital in a country also have a significantly positive effect on the strengthening of patent enforcement. Importantly, all five variables found to determine the strength of patent enforcement are variables that capture the level and quality of economic and social activity in a country, instead of more general variables that relate to e.g. the openness of an economy and political conditions.

Second, we study the determinants of the strength of patent law, focusing on the time period since the signing of TRIPS, which was not captured in the study of Ginarte and Park (1997). We find that the two main determinants that were significant in the Ginarte and Park (1997) study, the level of development of a country and R\&D expenditure, continue to have a positive effect on the strength of patent law. In addition, we find that the quality of human capital has a positive effect on the strength of patent law of a country. These are important findings that confirm the contemporary relevance of the Ginarte and Park (1997) study as well as highlight that some of the key determinants of strengthening levels of patent law continue to be the same as prior to the signing of TRIPS. Importantly, we also find that other variables which relate to the general economic and political conditions of a country such as market freedom, political freedom and openness do not have the expected effect on the strength of patent law anymore. The results showcase that after the signing of the TRIPS agreement, variables that relate to the general stance toward trade and the openness of a country no longer affect the strength of patent law, whereas variables that outline the footprint of the level and quality of economic and social activity in a country are important determinants.

This paper offers a statistical analysis of determinants of the strength of patent enforcement at the national level. To develop better understanding of how patent enforcement can be strengthened, future research could devote effort in the following areas. First, researchers could develop case studies to identify the dynamics and mechanisms with which patent and trademark users from different industries and countries influence the development of stronger patent enforcement. For example, anecdotal evidence suggests that in the preTRIPS years, the global pharmaceutical industry was influential in lobbying for the strengthening of patent law internationally. The results of our study suggest that in the years after TRIPS, patent and trademark users from a variety of different industries may have influenced the strength of patent enforcement. Second, and related to the above, as more 
firms become active users of patents and trademarks in a country, future research could analyze the educational activities undertaken by the national IP Offices to support firms in managing, protecting and creating value from their IP and in exploring and exploiting the value of IP owned by others, legally and ethically. Such studies could identify the effect of different educational activities in stimulating IP usage and identify the best educational practices to help develop patent enforcement strength in other countries.

\section{Policy implications}

The findings of this study have two important implications for policymakers at the national and supranational levels. First, the results suggest that policymakers who aim to strengthen patent enforcement activities need to take actions to educate and incentivize innovative firms to become familiar with and seek to protect their rights in the country. As UNCTAD (2015, p. 65) highlights in its Investment Policy Framework for Sustainable Development report, "As national investors are frequently less aware of their IP rights, they should be sensitized on the issue". Indeed, increasing the number of firms who actively engage with the patent and IP systems of the country will increase the number of firms who seek to commercialize their newly granted IP rights and who will monitor the market to identify when their rights are infringed by competitors. After identifying the infringement of their rights, the new IP owners as well as their collective industry associations will in turn apply pressure on the public patent enforcement agents who are responsible for enforcing patent law in practice (Yang et al., 2004).

A successful example of providing incentives that aim to increase the number of users of a patent system at the national level is found in the targets of China's $12^{\text {th }}$ five-year plan (2011-2015), which aimed to upgrade the capabilities of the Chinese manufacturing sector through scientific development. One of the targets was focused on providing monetary incentives to patent applicants, with an aim of increasing the number of patents in the country from 1.7 to 3.3 patents per 10,000 people in the time period (U.S.-China Economic and Security Review Commission, 2011). This target equalled a 100 per cent increase in the numbers of patents granted. It aimed to enable Chinese firms to become familiar with the benefits of the Chinese patent system and to upgrade their manufacturing capabilities by commercializing their registered innovations (U.S.-China Economic and Security Review Commission, 2011). Indeed, now that the number of patent applications and patents granted in China has risen exponentially over the last years, one of the next areas of focus identified in the Chinese government's $13^{\text {th }}$ five-year plan period is to "ensure strict IPR protection" 
(SIPO, 2016). Policymakers from other countries could provide similar monetary incentives to the Chinese ones, in order to expand the number of users of their patent system, since in the long term, this is expected to lead to the strengthening of patent enforcement in a country.

At the supranational level, policymakers could also consider providing indirect monetary incentives that can incentivize patent activity, by exploring ways to expand the country coverage of patent protection and (if possible) adopt a regional fee structure for the filing and renewal of patents in a group of countries. For example, the European Patent Office is planning to launch the "Unitary Patent" in 2019, a new form of patent protection that allows IP owners to receive uniform patent protection in 26 member countries of the European Union (EU) for a significantly reduced fee (EPO, 2018a). The unitary patent is expected to relieve innovators of the validation, translation and maintenance costs of patents in each of the $26 \mathrm{EU}$ countries, at a reduced fee that covers patent protection in all countries. The overall registration and maintenance cost of a unitary patent for 20 years is expected to be $€ 35,555$, whereas the equivalent cost of patent registration and maintenance in each of the 26 countries would be $€ 169,667$, a projected saving of $€ 134,112$ per patent (EPO, 2018b). ${ }^{6}$ The European Patent Office (EPO) also provides subsidies for small and medium enterprises (SMEs) and public research organizations, to incentivize them to register their rights (EPO, 2018a). National IP offices in other regions could follow the EPO's example and explore potential collaboration with neighboring countries and make it easier for patent owners to efficiently and cost-effectively receive patent protection in neighboring countries. The Chinese State IP Office has signed agreements with neighboring IP offices such as that of Cambodia, which agreed to validate Chinese patents as of 28 March 2018, and that of the Lao People's Democratic Republic, which agreed to recognize the Chinese patent examination results (Xinhua News, 2018a, 2018b). Such agreements further incentivize patenting activities by Chinese firms as patenting in China can enable the firms to easily expand their protection to other countries in the region.

With regard to the second recommendation, the findings of this study suggest that policymakers should aim to increase overall levels of $R \& D$ expenditure and invest in improving the quality of human capital in their country, since both will boost their country's innovation capability, which in turn leads to increased demand for stronger patent enforcement. This is in line with UNCTAD’s Investment Policy Framework for Sustainable Development report (2015, p. 42), which highlights that "businesses are more likely to invest

\footnotetext{
${ }^{6}$ The estimates are provided by the EPO using the national renewal fees that were valid as of 1 January 2017.
} 
resources in $R \& D$ and technological upgrading if their innovations are protected”. Therefore whereas our first recommendation focused on increasing the capacity of IP owners in a country, our second recommendation focuses on increasing the quality of the innovation outputs of IP owners. Investing in these two factors is expected to enable firms to engage with higher-level and more advanced technologies that are more likely to require an effective patent system, so that patent owners can successfully commercialize their assets (UNCTAD, 2014).

Policymakers can consider incentivizing firms to invest more in $R \& D$, particularly at the early experimental stages of research, which are more risky but, if successful, are expected to lead to the development of valuable IP assets. Contemporary studies generally find that $R \& D$ subsidies are expected to increase $R \& D$ output in the form of patents, especially in the European context (Buchman and Kaiser, 2018; Szczygielski et al., 2017). With regards to the findings of firms located in developed European countries, R\&D subsidies were found to increase the number of collaborative $R \& D$ projects of German biotechnology firms (Broekel and Boschma, 2011) and boost their patenting activity (Buchman and Kaiser, 2018). The same positive effect is found for R\&D subsidies to small and medium-sized Italian firms; however, the R\&D subsidy cost required to produce one additional patent is high, ranging between $€ 206,000$ and $€ 310,000$ (Szczygielski et al., 2017). A similar positive effect between R\&D subsidies and innovation is found for firms from European countries catching up on technology, such as Poland and Turkey (Bronzini and Pizelli, 2016).

An example of a successful R\&D subsidy program is the Scientific Research and Experimental Development Tax Incentive Program (SR\&ED) of the Canadian government which "encourages and supports scientific research and experimental development...by letting you deduct your SR\&ED costs from your income for tax purposes” (Government of Canada, 2018). SR\&ED incentives are considered an integral component of the Canadian innovation system, supporting innovative small and start-up businesses and attracting (and retaining) highly qualified human capital in the country (CPA, 2018). Importantly, such incentives can have a multiplying effect in terms of boosting investments in R\&D, since successful projects are expected to attract further cycles of $R \& D$ funding from internal or external sources. Overall, when policymakers consider developing such policies to influence the determinants of patent enforcement, they also need to simultaneously undertake reforms that directly aim to improve the functioning and effectiveness of patent systems. 


\section{References}

Ahammad, M.F., Konwar, Z., Papageorgiadis, N., Wang, C., Inbar, J. (2018). R\&D capabilities, intellectual property strength and choice of equity ownership in cross-border acquisitions: evidence from BRICS acquirers in Europe. R\&D Management, 48, (2), 177-194.

Alexiou, C., Nellis, J., Papageorgiadis, N. (2016). The effect of patent enforcement strength and FDI on economic growth. Multinational Business Review, 24, (4), 334-353.

Arora, A. (2009). Intellectual property rights and the international transfer of technology: setting out an agenda for empirical research in developing countries, in: World Intellectual Property Organization (WIPO) (Eds), The Economics of Intellectual Property: Suggestions for Further Research in Developing Countries and Countries with Economies in Transition. WIPO publication no. 1012(E), Geneva, pp. 41-58.

Barro, R. J., Lee, J. W. (1994). Sources of economic growth. Carnegie-Rochester Conference Series on Public Policy, 40, 1-46.

Broekel, T., Graf, H. (2012). Public research intensity and the structure of German R\&D networks: a comparison of 10 technologies. Economics of Innovation and New Technology, 21, (4), 345-372.

Bronzini, R., Piselli, P. (2016). The impact of R\&D subsidies on firm innovation. Research Policy, 45, (2), 442-457.

Buchmann, T., Kaiser, M. (2018). The effects of R\&D subsidies and network embeddedness on R\&D output: evidence from the German biotech industry. Industry and Innovation, forthcoming, 1-26.

Brander, J.A., Cui, V., Vertinsky, I. (2017). China and intellectual property rights: A challenge to the rule of law. Journal of International Business Studies, 48 (7), 908-921.

Correa, C. M. (2009). The push for stronger enforcement rules: implications for developing countries, in: Fink, C., Correa, C. M. (Eds), The Global Debate on The Enforcement of Intellectual Property Rights and Developing Countries. International Centre for Trade and Sustainable Development (ICTSD), pp. 31-59.

CPA (Chartered Professional Accountants Canada) (2018). Innovation nation: the power of SR\&D in Canada. Downloaded on 21 February 2019 from: https://www.cpacanada.ca/en/members-area/profession-news/2016/february/sred-taxincentives-in-canada.

Desyllas, P., Sako, M. (2013). Profiting from business model innovation: Evidence from PayAs-You-Drive auto insurance. Research Policy, 42, (1), 101-116.

Dunning, J. H., Zhang, F. (2008). Foreign direct investment and the locational competitiveness of countries. Transnational Corporations, 17, (3), 1-30. 
EPO (European Patent Office), (2018a). Unitary patent. Downloaded on 21 February 2019 from https://www.epo.org/law-practice/unitary/unitary-patent.html.

EPO (European Patent Office), (2018b). Cost of a Unitary Patent. Downloaded on 21 February 2019 from https://www.epo.org/law-practice/unitary/unitary-patent/cost.html.

Fink, C. (2009). Enforcing intellectual property rights: an economic perspective, in: Fink, C., Correa, C. M. (Eds), The Global Debate on the Enforcement of Intellectual Property Rights and Developing Countries. International Centre for Trade and Sustainable Development (ICTSD), pp. 1-25.

Financial Times (2018). Donald Trump lays out tariff plans for Chinese industrial goods. 4 April. Downloaded on 21 February 2019 from https:/www.ft.com/content/42fb1100-378f11e8-8eee-e06bde01c544.

Freedom House (2015). Freedom in the World. Downloaded on 21 February 2019 from https://freedomhouse.org/report/freedom-world/freedom-world-2015\#.WBdL64_XLIU.

Ginarte, J. C., Park, W. (1997). Determinants of patent rights: A cross-national study. Research Policy, 26, (3), 283-301.

Government of Canada, (2018). Claim your Scientific Research and Experimental Development (SR\&ED) tax incentives. Downloaded on 21 February 2019 from https://www.canada.ca/en/revenue-agency/campaigns/scientific-research-experimentaldevelopment.html.

Government of Singapore and Intellectual Property Office of Singapore (2017). Update to the intellectual property hub masterplan. Downloaded on 21 February 2019 from https://www.ipos.gov.sg/docs/default-source/about-ipos-doc/full-report_update-to-ip-hubmaster-plan_final.pdf.

Grossman, G. M., Lai, E. L. C, (2004). International protection of intellectual property. The American Economic Review, 94 (5), 1635-1653.

Heritage Foundation (2015). Index of economic freedom. Downloaded on 21 February 2019 from http://www.heritage.org/index.

Papageorgiadis, N., Cross, A., Alexiou, C. (2014). International patent systems strength 1998-2011. Journal of World Business, 49, (4), 586-597.

Papageorgiadis, N., McDonald, F. (2019). Defining and measuring the institutional underpinnings of intellectual property rights systems in a post-TRIPS World. Journal of International Management, forthcoming.

Papageorgiadis, N., Sharma, A. (2016). Intellectual property rights and innovation: A panel analysis. Economics Letters, 141, 70-72. 
Papageorgiadis, N., Xu, Y., Alexiou, C. (2019). The effect of European intellectual property institutions on Chinese outward foreign direct investment. Management Organization Review, forthcoming.

Park, W. G. (2008). International patent protection 1960-2005. Research Policy, 37, 761766.

Peng, M. W., Ahlstrom, D., Carraher, S. M., Shi, W. S. (2017). An institution-based view of global IPR History. Journal of International Business Studies, 48, (7), 893-907.

Pereira, A. (2006). Biotechnology foreign direct investment in Singapore. Transnational Corporations, 15, (2), 99-123.

Sachs, J. D., Warner, A., Åslund, A., Fischer, S. (1995). Economic reform and the process of global integration. Brookings Papers on Economic Activity, 1995, (1), 1-118.

SIPO (State Intellectual Property Office of China) (2016). New Year message 2016: making solid strides in the new journey of building a powerful IP country. Downloaded on 21 February 2019 from http://english.sipo.gov.cn/about/commissioner/201601/t20160115_1229191.html

Szczygielski, K., Grabowski, W., Pamukcu, M. T., Tandogan, V. S. (2017). Does government support for private innovation matter? Firm-level evidence from two catching-up countries. Research Policy, 46, (1), 219-237.

Taubman, A., Wager, H., Watal, J. (2012). A Handbook on the WTO TRIPs Agreement. Cambridge University Press, Cambridge, UK.

UK IP Office (2017). Fast facts. Downloaded on 21 February 2019 from https://assets.publishing.service.gov.uk/government/uploads/system/uploads/attachment_data /file/581279/Fast-Facts-2017.pdf.

UNCTAD (United Nations Conference on Trade and Development) (2010). World Investment Report 2013: Investing in a Low-Carbon Economy. Downloaded on 24 April 2018 from http://unctad.org/en/pages/DIAE/World\%20Investment\%20Report/WIRSeries.aspx?Re=11,5,,.

UNCTAD (United Nations Conference on Trade and Development), (2013). World Investment Report 2013: Global Value Chains, Investment and Trade for Development. $\begin{array}{lllll}\text { Downloaded } & \text { on } & 21 & \text { February } & 2019\end{array}$ http://unctad.org/en/pages/DIAE/World\%20Investment\%20Report/WIRSeries.aspx?Re=6,5,,.

UNCTAD (United Nations Conference on Trade and Development), (2014). World Investment Report 2014: Investing in the SDGs: An Action Plan. Downloaded on 21 February 2019 from http://unctad.org/en/pages/DIAE/World\%20Investment\%20Report/WIRSeries.aspx?Re=6,5,,. 
UNCTAD (United Nations Conference on Trade and Development), (2015). Investment Policy Framework for Sustainable Development. Downloaded on 21 February 2019 from https://unctad.org/en/pages/PublicationWebflyer.aspx?publicationid=1437.

U.S.-China Economic and Security Review Commission, (2011). Backgrounder: China's 12th five-year plan. Downloaded on 21 February 2019 from: http://origin.www.uscc.gov/sites/default/files/Research/12th-FiveYearPlan_062811.pdf

Ushijima, T. (2013). Patent rights protection and Japanese foreign direct investment. Research Policy, 42, (3), 738-748.

WIPO (World Intellectual Property Organization) (2015). WIPO IP statistics data center. Downloaded on 21 February 2019 from: http://ipstats.wipo.int/ipstatv2/index.htm.

Word Bank (2015a). GDP per capita (current US\$). Downloaded on 21 February 2019 from http://data.worldbank.org/indicator/NY.GDP.PCAP.CD.

Word Bank (2015b). Research and development expenditure (\% of GDP). Downloaded on 21 February 2019 from http://data.worldbank.org/indicator/GB.XPD.RSDV.GD.ZS.

Word Bank, (2015c). Gross enrolment ratio, secondary, both sexes (\%). Downloaded on 21 February 2019 from http://data.worldbank.org/indicator/SE.SEC.ENRR.

Word Bank (2015d). Exports of goods and services (BoP, current US\$). Downloaded on 21 February 2019 from http://data.worldbank.org/indicator/BX.GSR.GNFS.CD.

Word Bank (2015e). Imports of goods and services (BoP, current US\$). Downloaded on 21 February 2019 from http://data.worldbank.org/indicator/NE.IMP.GNFS.ZS.

Word Bank (2015f). Foreign direct investment, net inflows (BoP, current US\$). Downloaded on 21 February 2019 from http://data.worldbank.org/indicator/BX.KLT.DINV.CD.WD.

WTO (World Trade Organization) (2018). Annex 1c: Agreement on Trade-Related Aspects of Intellectual Property Rights. Downloaded on 21 February 2019 from https://www.wto.org/english/docs_e/legal_e/27-trips.doc.

Xinhua news (2018a). Chinese patents to be valid in Cambodia: official. Downloaded on 21 February 2019 from http://www.xinhuanet.com/english/2018-03/02/c_137011853.htm.

Xinhua news (2018b). China, Laos sign MoU on intellectual property cooperation. Downloaded on 21 February 2019 from http://www.xinhuanet.com/english/201804/02/c_137083496.htm.

Yang, D., Sonmez, M. Bosworth, D. (2004). Intellectual property abuses: how should multinationals respond? Long Range Planning, 37 (5), 459-475.

Zhang, Y., Li, H., Li, Y., Zhou, L. (2010). FDI spillovers in an emerging market: the role of foreign firms' country origin diversity and domestic firms' absorptive capacity. Strategic Management Journal, 31, (9), 969-989. 
Figure 1: Determinants of strength of patent law and strength of patent law enforcement

Factors determining incentives

- Factors affecting aggregate output level: (i) human capital, (ii) R\&D investment

- Factors affecting aggregate price level: (i) openness to trade, (ii) market freedom, (iii) political freedom.

- Infrastructure cost: developing and operating patent law infrastructure (relative to national income per capita) (Adapted from Ginarte and Park, 1997)

\section{Pressure factors}

- Pressure from intellectual property rights owners who operate in a country: (i) number of patents, (ii) number of trademarks

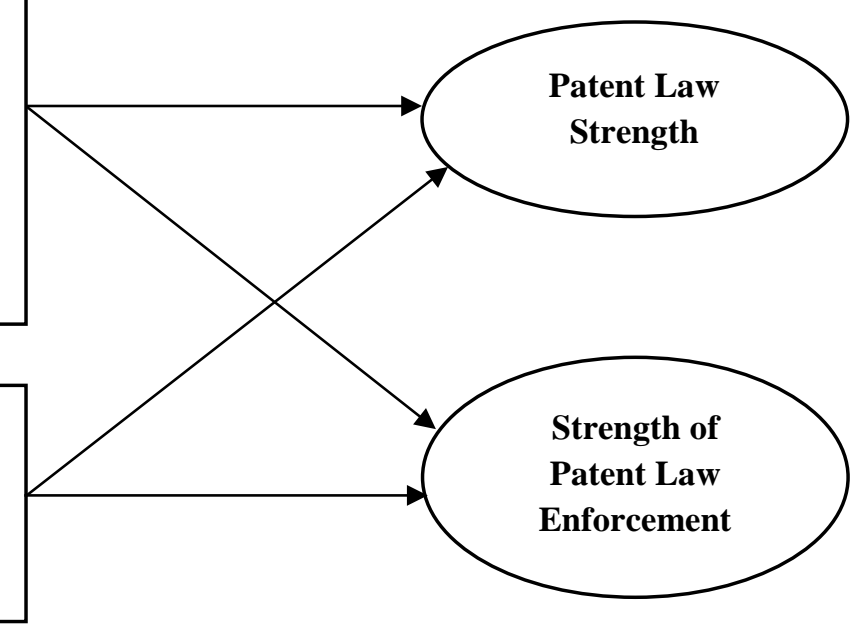


Table 1. Variable description, measurement and sourcesError! Not a valid link.

\begin{tabular}{|c|c|c|}
\hline Variable & Description/Measurement & Data Source \\
\hline Patent law strength & Index by Park (2008) & Park (2008) \\
\hline $\begin{array}{l}\text { Enforcement strength of patent } \\
\text { law }\end{array}$ & $\begin{array}{l}\text { Index by Papageorgiadis et al. } \\
\text { (2014) }\end{array}$ & Papageorgiadis et al. (2014) \\
\hline GDP per capita & Logarithm of real GDP per capita & World Bank (2015a) \\
\hline R\&D / GDP & $\begin{array}{l}\% \text { of research and development } \\
\text { expenditure over GDP }\end{array}$ & World Bank (2015b) \\
\hline Secondary enrolment & $\begin{array}{l}\% \text { of population that it is enrolled in } \\
\text { secondary schools }\end{array}$ & World Bank (2015c) \\
\hline Political freedom & $\begin{array}{l}\text { Measure of political risk in which } \\
\text { higher values indicate a riskier } \\
\text { environment }\end{array}$ & Freedom House (2015) \\
\hline Market freedom & $\begin{array}{l}\text { Measure of market freedom in } \\
\text { which higher values indicate more } \\
\text { freedom in business transactions }\end{array}$ & Heritage Foundation (2015) \\
\hline Openness & $\begin{array}{l}\text { Sum of volume of exports plus } \\
\text { imports over GDP }\end{array}$ & World Bank (2015d, 2015e) \\
\hline $\begin{array}{l}\text { Trademark applications per } \\
\text { capita }\end{array}$ & $\begin{array}{l}\text { Logarithm of applications to register } \\
\text { a trademark with a national or } \\
\text { regional intellectual property (IP) } \\
\text { office over population }\end{array}$ & WIPO (2015) \\
\hline FDI / GDP & $\begin{array}{l}\text { Sum of foreign assets and liabilities } \\
\text { over GDP }\end{array}$ & World Bank (2015f) \\
\hline Patent applications per capita & $\begin{array}{l}\text { Logarithm of worldwide patent } \\
\text { applications filed through the Patent } \\
\text { Cooperation Treaty procedure or } \\
\text { with a national patent office for } \\
\text { exclusive rights for an invention } \\
\text { over population }\end{array}$ & WIPO (2015) \\
\hline
\end{tabular}


Table 2. Descriptive statistics

\begin{tabular}{lcccc}
\hline \hline Variable & Mean & SD & Min & Max \\
\hline \hline Patent law strength & 3.987 & 0.662 & 1.08 & 4.67 \\
Enforcement strength of patent & 6.42 & 2.126 & 2.6 & 9.9 \\
law & 9.486 & 1.191 & 6.271 & 11.124 \\
GDP per capita & 1.441 & 1.082 & 0.01 & 4.835 \\
R\&D / GDP & 96.747 & 13.476 & 42.298 & 160.619 \\
Secondary enrolment & 1.804 & 1.475 & 1 & 7 \\
Political freedom & 74.213 & 12.979 & 36.3 & 100 \\
Market freedom & 88.083 & 57.086 & 18.756 & 446.754 \\
Openness & 0.046 & 0.099 & 0.002 & 1.307 \\
Trademark applications per capita & 0.817 & 1.153 & 0.04 & 11.034 \\
FDI / GDP & 0.05 & 0.074 & 0.004 & 0.355 \\
Patent applications per capita & & & & \\
\hline
\end{tabular}


Table 3. Correlation coefficients

\begin{tabular}{|c|c|c|c|c|c|c|c|c|c|c|c|}
\hline & $\begin{array}{c}\text { Patent } \\
\text { law } \\
\text { strength }\end{array}$ & $\begin{array}{l}\text { Enforcement } \\
\text { strength of } \\
\text { patent law }\end{array}$ & $\begin{array}{c}\text { GDP } \\
\text { per } \\
\text { capita }\end{array}$ & $\begin{array}{c}\mathrm{R} \& \mathrm{D} / \\
\mathrm{GDP}\end{array}$ & $\begin{array}{l}\text { Secondary } \\
\text { enrolment }\end{array}$ & $\begin{array}{l}\text { Political } \\
\text { freedom }\end{array}$ & $\begin{array}{l}\text { Market } \\
\text { freedom }\end{array}$ & Openness & $\begin{array}{l}\text { Trademark } \\
\text { applications } \\
\text { per capita }\end{array}$ & $\begin{array}{l}\text { FDI / } \\
\text { GDP }\end{array}$ & $\begin{array}{c}\text { Patent } \\
\text { applications } \\
\text { per capita }\end{array}$ \\
\hline Patent law strength & 1 & & & & & & & & & & \\
\hline $\begin{array}{l}\text { Enforcement } \\
\text { strength of patent } \\
\text { law }\end{array}$ & 0.525 & 1 & & & & & & & & & \\
\hline GDP per capita & 0.679 & 0.834 & 1 & & & & & & & & \\
\hline R\&D / GDP & 0.493 & 0.662 & 0.664 & 1 & & & & & & & \\
\hline $\begin{array}{l}\text { Secondary } \\
\text { enrolment }\end{array}$ & 0.622 & 0.671 & 0.755 & 0.542 & 1 & & & & & & \\
\hline Political freedom & -0.502 & -0.563 & -0.661 & -0.39 & -0.533 & 1 & & & & & \\
\hline Market freedom & 0.385 & 0.684 & 0.682 & 0.401 & 0.461 & -0.484 & 1 & & & & \\
\hline Openness & -0.072 & 0.136 & 0.111 & -0.099 & -0.087 & -0.036 & 0.266 & 1 & & & \\
\hline $\begin{array}{l}\text { Trademark } \\
\text { applications per } \\
\text { capita }\end{array}$ & 0.479 & 0.025 & 0.407 & 0.169 & 0.299 & -0.209 & 0.494 & 0.353 & 1 & & \\
\hline FDI / GDP & 0.159 & 0.343 & 0.309 & 0.057 & 0.082 & -0.204 & 0.424 & 0.779 & 0.368 & 1 & \\
\hline $\begin{array}{l}\text { Patent applications } \\
\text { per capita }\end{array}$ & 0.643 & 0.368 & 0.646 & 0.634 & 0.461 & -0.346 & 0.545 & 0.131 & 0.532 & 0.225 & 1 \\
\hline
\end{tabular}


Table 4. Regression results for the determinants of the strength of patent law

\begin{tabular}{lccc}
\hline & $(1)$ & $(2)$ & $(3)$ \\
& Patent law strength & Patent law strength & Patent law strength \\
\hline GDP per capita & $0.358^{* * *}$ & $0.349^{* * *}$ & $0.376^{* * *}$ \\
R\&D / GDP & {$[0.0315]$} & {$[0.0290]$} & {$[0.0323]$} \\
& $0.0556^{* * *}$ & $0.0573^{* *}$ & $0.0535^{* *}$ \\
Secondary enrolment & {$[0.0215]$} & {$[0.0233]$} & {$[0.0214]$} \\
& $0.00149^{*}$ & $0.00232^{* * *}$ & $0.00173^{* *}$ \\
Political freedom & {$[0.000869]$} & {$[0.000820]$} & {$[0.000861]$} \\
& 0.00398 & 0.00522 & 0.00348 \\
Market freedom & {$[0.00999]$} & {$[0.00939]$} & {$[0.0100]$} \\
& $-0.00231^{* * *}$ & $-0.00197^{* * *}$ & $-0.00218^{* * *}$ \\
Openness & {$[0.000684]$} & {$[0.000652]$} & {$[0.000679]$} \\
& -0.000558 & $-0.000621^{*}$ & $-0.000593^{*}$ \\
Trademark applications per capita & {$[0.000359]$} & {$[0.000345]$} & {$[0.000356]$} \\
& $-0.440^{* * *}$ & & $-0.270^{*}$ \\
FDI / GDP & {$[0.137]$} & & {$[0.158]$} \\
& 0.0183 & $0.0256^{*}$ & 0.0205 \\
Patent applications per capita & {$[0.0157]$} & {$[0.0145]$} & {$[0.0155]$} \\
& & -0.409 & $-0.705^{* *}$ \\
Constant & & {$[0.310]$} & {$[0.316]$} \\
& $0.498^{*}$ & $0.495^{*}$ & 0.333 \\
\hline LR (Heteroscedasticity) Test & {$[0.285]$} & {$[0.269]$} & {$[0.293]$} \\
Wooldridge (Autocorrelation) Test & $2012.432^{* * *}$ & $621.70^{* * * *}$ & $568.09^{* * *}$ \\
No. of observations & & 1000.628 & $961.833^{* * *}$ \\
\hline 1. Standard errors in brackets. & 546 & & 546 \\
2. ${ }^{*} p<0.10,{ }^{* *} p<0.05,{ }^{* * *} p<0.01$. & & 559 & \\
3. Feasible general least squares estimator is applied, assuming a heteroskedastic error structure with no cross-sectional correlation and AR(1).
\end{tabular}


Table 5. Regression results for the determinants of the strength of patent law enforcement in practice

\begin{tabular}{|c|c|c|c|}
\hline & $\begin{array}{c}\text { (1) } \\
\text { Enforcement } \\
\text { strength of patent } \\
\text { law }\end{array}$ & $\begin{array}{c}\text { (2) } \\
\text { Enforcement } \\
\text { strength of patent } \\
\text { law }\end{array}$ & $\begin{array}{c}\text { (3) } \\
\text { Enforcement } \\
\text { strength of patent } \\
\text { law } \\
\end{array}$ \\
\hline GDP per capita & $\begin{array}{l}0.956^{* * *} \\
{[0.0613]}\end{array}$ & $\begin{array}{l}1.179^{* * *} \\
{[0.0705]}\end{array}$ & $\begin{array}{l}0.929^{* * *} \\
{[0.0599]}\end{array}$ \\
\hline R\&D / GDP & $\begin{array}{l}0.427^{* * *} \\
{[0.0642]}\end{array}$ & $\begin{array}{l}0.246^{* * *} \\
{[0.0642]}\end{array}$ & $\begin{array}{l}0.373^{* * *} \\
{[0.0668]}\end{array}$ \\
\hline Secondary enrolment & $\begin{array}{l}0.00516^{* *} \\
{[0.00231]}\end{array}$ & $\begin{array}{l}0.00876^{* * *} \\
{[0.00212]}\end{array}$ & $\begin{array}{l}0.00542^{* *} \\
{[0.00225]}\end{array}$ \\
\hline Political freedom & $\begin{array}{l}-0.0380 \\
{[0.0239]}\end{array}$ & $\begin{array}{l}-0.0347 \\
{[0.0222]}\end{array}$ & $\begin{array}{l}-0.0389^{*} \\
{[0.0227]}\end{array}$ \\
\hline Market freedom & $\begin{array}{c}0.00194 \\
{[0.00216]}\end{array}$ & $\begin{array}{l}0.00392^{* *} \\
{[0.00199]}\end{array}$ & $\begin{array}{c}0.00196 \\
{[0.00216]}\end{array}$ \\
\hline Openness & $\begin{array}{l}0.0000661 \\
{[0.000849]}\end{array}$ & $\begin{array}{c}0.00100 \\
{[0.000741]}\end{array}$ & $\begin{array}{l}-0.000152 \\
{[0.000816]}\end{array}$ \\
\hline Trademark applications per capita & $\begin{array}{l}0.164^{* * *} \\
{[0.0305]}\end{array}$ & & $\begin{array}{l}0.140^{* * *} \\
{[0.0304]}\end{array}$ \\
\hline FDI / GDP & $\begin{array}{l}0.0950^{* * *} \\
{[0.0328]}\end{array}$ & $\begin{array}{c}0.0154 \\
{[0.0283]}\end{array}$ & $\begin{array}{l}0.0849^{* * *} \\
{[0.0306]}\end{array}$ \\
\hline Patent applications per capita & & $\begin{array}{c}0.0617^{*} \\
{[0.0319]}\end{array}$ & $\begin{array}{l}0.113^{* * *} \\
{[0.0321]}\end{array}$ \\
\hline Constant & $\begin{array}{c}-3.105^{* * *} \\
{[0.513]}\end{array}$ & $\begin{array}{c}-5.641^{* * *} \\
{[0.619]}\end{array}$ & $\begin{array}{c}-2.393^{* * *} \\
{[0.524]}\end{array}$ \\
\hline $\begin{array}{l}\text { LR (Heteroscedasticity) Test } \\
\text { Wooldridge (Autocorrelation) Test }\end{array}$ & $\begin{array}{l}419.53 * * * \\
68.179 * * *\end{array}$ & $\begin{array}{l}435.53 * * * \\
73.159 * * *\end{array}$ & $\begin{array}{l}460.28 * * * \\
69.278 * * *\end{array}$ \\
\hline No. of Observations & 546 & 559 & 546 \\
\hline
\end{tabular}

Note:

1. Standard errors in brackets.

2. ${ }^{*} p<0.10,{ }^{* *} p<0.05,{ }^{* * *} p<0.01$.

3. Feasible general least squares estimator is applied, assuming a heteroskedastic error structure with no cross-sectional correlation and AR(1). 